\title{
UNC13B wt Allele
}

National Cancer Institute

\section{Source}

National Cancer Institute. UNC13B wt Allele. NCI Thesaurus. Code C52953.

Human UNC13B wild type allele is located within 9p12-p11 and is approximately $243 \mathrm{~kb}$ in length. This allele, which encodes Unc-13 homolog B protein, is involved in the regulation of both the diacylglycerol second messenger pathway and synaptic vesicle exocytosis. 